\title{
APPEASEMENT CHINA TERHADAP INDONESIA ATAS PERCOBAAN PENEGAKAN KLAIM DI ZEE NATUNA (KASUS DESEMBER 2019 - JANUARI 2020)
}

\author{
Adnan Hudianto \\ Departemen Ilmu Hubungan Internasional \\ Fakultas Ilmu Sosial dan Ilmu Politik \\ Universitas Indonesia \\ Email : hudianhudian211@gmail.com
}

\begin{abstract}
ABSTRAK
Tulisan ini membahas tentang perubahan implementasi kebijakan luar negeri China terhadap Indonesia terkait penegakan klaim Nine Dash Line di Zona Ekonomi Eksklusif (ZEE) Natuna yang terjadi pada rentang waktu Desember 2019 s.d. Januari 2020. China mengirimkan kapal nelayan, penjaga pantai dan militernya ke wilayah ZEE Natuna. Pemerintah Indonesia merespon aksi tersebut dengan mengirimkan nota protes kepada pihak China namun tidak mendapat tanggapan. Kemudian, Indonesia bersikap lebih tegas lagi dengan mengirimkan militernya ke wilayah ZEE Natuna disertai dengan pernyataan Presiden Indonesia bahwa pihak Indonesia serius dalam mempertahankan wilayah berdaulatnya. Menanggapi hal tersebut, China yang jauh lebih unggul dari segi power mengubah perilakunya dan justru melakukan appeasment. Perubahan perilaku China ini dianalisis dengan menggunakan teori Foreign Policy Decision Making. Metode penelitian yang digunakan adalah metode kualitatif dengan pendekatan deskriptif analitis. Argumen utama tulisan ini adalah bahwa pengambil keputusan China mengalami overgeneralisasi, terpengaruh emotions dan memperoleh informasi yang bersifat time constraint. Respon tegas Indonesia berada di luar dugaan pihak China dan jika diteruskan hal ini dapat membahayakan strategi detterence China atas Amerika Serikat di Laut China Selatan. Mengingat Indonesia dipandang memiliki regime type of adverseries sebagai negara yang cenderung menghindari konflik, maka China memutuskan untuk melakukan dynamic setting dengan mengubah pendekatan menjadi lebih lunak.
\end{abstract}

Kata Kunci : Kebijakan Appeasement, Foreign Policy Decision Making, ZEE Natuna, Kebijakan Luar Negeri China

\section{ABSTRACT}

This paper discusses about the changes of China's implementation of claim enforcement on Indonesia's EEZ in Natuna that happened between December 2019 to January 2020. In order to enforce its claim over the EEZ Natuna, China sends fishing boat, coast guard ship and the PLA-N warship. Indonesian Government responded by lodging diplomatic protest to Chinese Government but was ignored. Indonesia's side tighten the pressure by sending its warship to the dispute location and finally make China which has more power capabillity do an appeasement. The changes of China's behavior will be analized using Foreign Policy and Decision making theory, qualitative method and descriptive analitical approach. The main argument of this paper is the China's decision maker was experiencing overgeneralitation, drived by the emotions, and get time constrained information. Assertive response by Indonesian Government was not expected by China's side and if China continue its assertive policy in EEZ Natuna area it could endanger their detterence strategy towards United States of America in South China Sea. Considering Indonesia has an image ally and the regime type of adverserires as peacefull state, China decided to do the dynamic setting by soften its approach towards Indonesia.

Keywords : Appeasement policy, Foreign Policy Decision Making, EEZ Natuna, China Foreign Policy 


\section{PENDAHULUAN}

Pada tahun 1960-an, Pemerintah China mengkalim bahwa seluruh pulau di Laut China Selatan (termasuk perairan dalam sembilan garis putus-putus atau (Nine Dash Line) adalah milik mereka. Hal ini menimbulkan sengketa perbatasan antara China dengan negara-negara claimant state yang ada di Asia Tenggara. Klaim China tersebut dilakukan secara unilateral dan berubah-ubah. Hal ini memicu konflik teritorial dan sejumlah Maritime Spat antara kapal China dengan negara Asia Tenggara termasuk Indonesia (Kartikasari, 2019). Maritime Spat antara Indonesia dengan pihak China terjadi pada tahun 2010, 2013 dan 2016 di ZEE Natuna. Di tahun 2016, Maritime Spat terjadi sebanyak tiga kali dimana pihak Indonesia melakukan pengerahan kapal militer untuk menghalau kapal nelayan dan kapal penjaga pantai China (Connelly, 2017). Serangkaian Maritime Spat tersebut menyebabkan pihak Kedutaan Besar China di Jakarta pada tahun 2016 akhirnya bahwa klaim China atas Laut China Selatan turut melingkupi ZEE Natuna (Kartikasari, 2019).

Pada bulan Desember 2019 China kembali mengirimkan kapal nelayannya ke wilayah ZEE Natuna namun kali ini dengan pengawalan penjaga pantai serta kapal militer jenis Fregrat (CNN, 2020a). Pihak Indonesia menganggap bahwa pihak China telah melanggar wilayah berdaulat mereka di ZEE Natuna yang legalitasnya dijamin sesuai dengan kesepakatan UNCLOS 1982 (Kompas, 2020d). Untuk itu, Kementerian Luar Negeri Indonesia menyampaikan nota protes kepada Kementerian Luar Negeri China dan meminta agar pihak China segera menarik mundur kapal-kapal miliknya. Pihak Indonesia juga mulai mengerahkan angkatan bersenjata Indonesia ke wilayah ZEE Natuna (Detik, 2020a). Kementerian Luar Negeri China merespon dengan pernyataan bahwa China berhak atas Laut China Selatan termasuk ZEE Natuna (relevant water) dan menolak permintaan pihak Indonesia untuk menarik mundur kapal mereka dari ZEE Natuna. Kementerian Luar Negeri China menyatakan bahwa sikap China tidak akan berubah meskipun Indonesia menolak kalim China (CNBC, 2020). Pihak China tetap memutuskan untuk mempertahankan kehadiran kapal militernya di ZEE Natuna (Detik, 2020b).

Dengan kapasitas militer yang lebih kuat seharusnya China mempertahankan sikapnya dalam penegakan klaim di ZEE Natuna dengan tidak menghiraukan pengerahan militer dan protes Indonesia. Namun setelah jumlah kehadiran militer Indonesia di wilayah Natuna bertambah dan Presiden Indonesia mengeluarkan statement bahwa ZEE Natuna adalah milik Indonesia, China justru melakukan Appeasement. China menarik kapal militernya dari ZEE Natuna dan Kementerian Luar Negeri China mengubah pernyataan "bahwa Indonesia adalah mitra strategis China, maka penyelesaian perbedaan klaim ZEE Natuna dilakukan dengan cara yang kondsuif melalui diplomasi" (Detik, 2020b). Pada 13 Januari 
2020, kapal perang Indonesia mengusir seluruh kapal nelayan China dari ZEE Natuna tanpa mendapat perlawanan dari kapal penjaga pantai dan kapal perang China (Kompas, 2020e).

Appeasement adalah kebijakan sebuah negara yang memperbolehkan negara lainnya mendapatkan apa yang ingin mereka dapatkan demi menghindarkan konflik bersenjata (Viotti \& Kauppi, 2012). Kebijakan tersebut umumnya dilakukan oleh negara yang lebih lemah militernya, akan tetapi dalam beberapa kasus Appeasement juga bisa dilakukan oleh negara big power terhadap negara yang lebih lemah secara militer seperti Inggris terhadap Irlandia ataupun AS terhadap Iran (Küntzel, 2014). Diketahui bahwa China adalah negara yang memiliki power jauh lebih besar dibandingkan Indonesia. Berdasarkan pengukuran Composite Index of National Capability tahun 2001 Indonesia memiliki power dengan jumlah 0,017 sedangkan China memiliki power dengan jumlah 0,134 atau berada di urutan kedua dunia setelah Amerika Serikat dengan 0,150 (Chan, 2005). Sedangkan menurut situs Global Firepower, pada tahun 2019 kekuatan militer Indonesia menempati urutan ke-16 dunia sedangkan China menempati urutan ke-3 dunia.

Kajian akademis tentang perilaku China secara umum maupun perilaku Appeasement China terhadap Indonesia terkait sengketa klaim di ZEE Natuna masih sangat sedikit atau bersifat understudy. Dengan demikian, beberapa kajian yang menjadi acuan literature review tulisan kali ini turut mengikutsertakan tulisan tentang Appeasement negara Asia Tenggara lain yang memiliki konflik geografis serupa dengan China. Selain itu, tulisan tentang Appeasement negara big power lain terhadap negara yang lebih lemah juga turut menjadi acuan literature review. Kajian terdahulu yang menjadi pijakan bagi penulisan Appeasement China terhadap Indonesia di Laut China Selatan terbagi menjadi tiga kategori, yakni : (1) Perilaku China dalam sengketa Laut China Selatan (2) Appeasement Filipina terhadap China dalam sengketa teritorial di Laut China Selatan, dan (3) Perilaku Appeasement negara big powers.

Kajian terdahulu tentang Perilaku China dalam sengketa Laut China Selatan dibahas menggunakan konsep Image dan konsep Appeasement (Kartikasari, 2019; Niquet, 2019). Sedangkan kajian terdahulu tentang Appeasement Filipina terhadap China dalam sengketa Laut China Selatan dibahas menggunakan konsep balance of power (De Castro, 2019a), konsep fear and foreign policy (De Castro, 2019b), konsep soft balancing (Castro, 2020), konsep Appeasement (De Castro, 2019c) dan balancing (Cruz de Castro, 2017). Terakhir, kajian terdahulu tentang perilaku Appeasement negara big powers menggunakan konsep Appeasement (Kennedy, 1976) dan historical analysis (Chang, 2003).

Dari kajian terdahulu tentang Perilaku China dalam sengketa Laut China Selatan dapat disimpulkan bahwa sikap China terhadap Indonesia yang tidak tegas dalam penegakan klaim atas Laut China Selatan di ZEE Indonesia disebabkan karena China menganggap Indonesia memiliki ally image, 
dimana Indonesia dipandang sebagai aktor yang dapat bekerja sama, serta memiliki kapabilitas dan dimensi kultural yang setara. Selain itu, China memberlakukan policy Appeasement untuk mendelegitimasi putusan Permanent Court of Arbitration tahun 2016 yang dapat digunakan sebagai pijakan negara Asia Tenggara khususnya Filipina untuk mementahkan klaim China. Melalui Appeasement tersebut, China berharap agar kondsuifitas klaim Nine Dash Line milikinya klaimnya dapat terjaga dalam jangka panjang.

Sedangkan dari kajian terdahulu tentang Appeasement Filipina terhadap China dalam sengketa teritorial dapat disimpulkan bahwa sikap Appeasement Filipina yang ditunjukkan di era Presiden Duterte terjadi akibat kepentingan pragmatis ekonomi yang menjadi fokus utama pemerintahan Duterte. Belt and Road Initiative (BRI) yang dijalankan China merupakan alasan utama mengapa Filipina melakukan Appeasement terhadap kebijakan ekspansionis China di wilayah perairannya. Selain itu, permasalahan pemberantasan narkotika domestik dalam negeri Filipina juga turut menjadi penyebab Appeasement Filipina terhadap China.

Dari kajian terdahulu tentang Perilaku Appeasement negara big power s dapat disimpulkan bahwa umumnya negara big power s melakukan Appeasement akibat faktor ekonomi, domestik dan over-extension. Selain itu, Appeasement juga dapat disebabkan akibat lobby negara musuh atau pro negara musuh yang berhasil di pemerintahan. Faktor kepentingan strategis juga dapat menyebabkan negara yang lebih besar untuk melakukan Appeasement terhadap negara revisionis yang lebih kecil.

Hasil literature review menunjukkan bahwa belum ditemukan adanya pengkaji Ilmu Hubungan Internasional yang membahas tentang perilaku appeasment China terhadap Indonesia terkait konflik di ZEE Natuna. Umumnya, studi tentang Appeasement terdekat baru mengkaji Appeasement Filipina terhadap China dalam konflik geografis di Laut China Selatan. Padahal Appeasement China terhadap Indonesia menunjukkan sebuah fenomena Appeasement big power terhadap negara middle power yang relatif langka terjadi dalam hubungan internasional. Untuk itu, tulisan ini mencoba mengisi gap yang belum ada pada penelitian sebelumnya.

Mengacu pada statistik power, China dapat saja mengabaikan penyiagaan militer Indonesia di ZEE Natuna karena apabila terjadi perang di antara kedua pihak, China yang lebih kuat secara militer berpotensi besar memenangkan konflik bersenjata tersebut. Konfrontasi pernah dilakukan China terhadap Vietnam yang mencoba mengusir kehadiran militer China dari Kepulauan Paracel dan Spratly yang sebelumnya adalah milik Vietnam. Hasil konfrontasi tersebut dimenangkan China sekaligus mengakhiri kontestasi Vietnam atas wilayah Kepulauan Spratly dan Paracel (Fravel \& Fravel, 2018). China justru melakukan appeasment dengan menarik mundur kapal militernya dan mengubah pernyataannya terkait 
Natuna setelah pihak Indonesia mengerahkan militernya dan mengeluarkan pernyataan tegas untuk melindungi ZEE Natuna. Dengan demikian, pertanyaan penelitian dalam tulisan ini adalah mengapa negara Big Power China yang mencoba menegakkan klaimnya di ZEE Natuna justru melakukan Appeasement setelah mendapat respon assertive dari Indonesia?

Sikap keras yang sempat ditunjukkan China terjadi akibat pengambil keputusan China mengalami overgeneralisasi, terpengaruh emotions serta opini publik dan memperoleh informasi yang bersifat time constraint. Jika China meneruskan sikapnya yang bersikeras mempertahankan militernya di ZEE Natuna, maka hal tersebut berpotensi membahayakan strategi detterence China atas Amerika Serikat di Laut China Selatan. Mengingat Indonesia adalah negara yang dipandang memiliki image ally serta negara dengan regime type of adverseries yang cenderung menghindari konflik, maka China memutuskan untuk melakukan dynamic setting dengan mengubah kebijakan yang sebelumnya bersikeras keras menjadi Appeasement.

Dalam tulisan ini, perilaku appeasment China terhadap Indonesia yang terjadi sehubungan dengan sengketa geografis pada bulan Desember 2019 s.d. Januari 2020 akan diulas menggunakan teori Foreign Policy Decision Making. Pertama, isi dari teori tersebut akan dijelaskan secara gambalang dalam kerangka analisa. Selanjutnya 4 buah determinan dari teori Foreign Policy Decision Making akan menjadi acuan untuk menganalisa penyebab Appeasement China terhadap Indonesia. Kemudian, tulisan ini akan ditutup dengan kesimpulan dari hasil analisa.

\section{KERANGKA ANALISIS}

Fenomena Appeasement China terhadap Indonesia yang menjadi research question akan dibahas menggunakan teori Foreign Policy Decision Making. Sebagaimana diketahui Appeasement merupakan perwujudan dari kebijakan luar negeri sebuah negara sedangkan kebijakan luar negeri sebuah negara adalah objek kajian dari teori Foreign Policy Decision Making (Aster, 2008; Trubowitz \& Harris, 2015). Dengan demikian, teori tersebut dianggap relevan karena dapat menjelaskan fenomena kebijakan luar negeri apapun termasuk Appeasement. Foreign Policy Decision Making akan menjelaskan mengapa opsi Appeasement terhadap Indonesia diambil para pembuat kebijakan di China serta bagaimana hal tersebut dilakukan. Selain itu, Mintz dan DeRouen dalam bukunya berjudul Understanding Foreign Policy Decision Making juga secara khusus menegaskan bahwa Appeasement merupakan perwujudan dari kebijakan luar negeri yang merupakan objek kajian teori Foreign Polici Decision Making (Mintz \& DeRouen, 2010). Atas dasar tersebut, fenomena Appeasement China terhadap Indonesia dalam sengketa geografis di ZEE Natuna akan dikaji menggunakan teori Foreign Policy Decision Making. 
Teori Foreign Policy Decision Making lahir pada tahun 1960-an dan termasuk ke dalam paradigma liberal karena mengkombinasikan interdependensi, globalisasi dan variabel independen dalam melihat perilaku pengambilan keputusan luar negeri negara (Viotti \& Kauppi, 2012). Ilmuwan HI seperti Richard Synder, H. W. Bruck dan Burton Spin (dikenal juga sebagai SBS) awalnya menemukan genre ilmu Hubungan Internasional yang membedah state dan society untuk melihat perilaku pengambilan kebijakan negara. Hal ini membantah salah satu argumen utama paradigma realis, bahwa state bersifat unifed actor. Selanjutnya, ilmuwan HI lainnya yakni Valerie Hudson mengembangkan teori Foreign Policy Decision Making dengan lebih memfokuskan cara pandang terhadap agent atau aktor di bawah level state (Mintz \& DeRouen, 2010). Selanjutnya, Mintz dan DeRouen memperdalam teori ini dengan mempertimbangkan gabungan antara faktor situasi, faktor psikologis pimpinan, faktor internasional dan faktor domestik.

Foreign Policy Decision Making memiliki empat buah determinan yakni ; (1)Decision Environment; (2) Psychological Factors, (3) International Factros, dan (4) Domestic Factors (Mintz \& DeRouen, 2010). Karakteristik Decision envirionment mempengaruhi pengambilan keputusan dari pemimpin negara. Kebijakan luar negeri biasanya dilakukan dalam periode waktu yang singkat dengan tekanan dan informasi yang ambigu. Pengambil keputusan akan berhadapan dengan ketidakpastian, stress, familiarity, persepsi ancaman dan resiko serta akuntabilitas. Beberapa ilmuwan HI berpendapat bahwa stress dan ancaman eksternal dapat berdampak pada peningkatan kekakuan pengambilan keputusan dan ketergantungan yang berlebihan terhadap standard operating procedures/ SOP (Renshon \& Renshon, 2008). Denomoinator umum dari faktor-faktor yang memediasi serangan keputusan strategis dalam permintaan kognitif dilakukan oleh keputusan yang harus dikerjakan penugasan. Semakin berat permintaan kognitif (sebagai contoh semakin ambigu dan tidak familiar terhadap keputusan yang harus dikerjakan) maka pengambil keputusan akan semakin menggunakan simplifikasi (jalan pintas kognitif) sehingga pengambilan keputusan sering berada dalam bentuk yang mengalir. Krisis Foreign Policy ditandai dengan bervolusinya pilihan-pilihan ketika alternatif keputusan muncul selama proses (Mintz \& DeRouen, 2010).

Decision Environment ditentukan oleh beberapa faktor yakni time contraints, familiarity, dynamic setting, risk dan stress (Mintz \& DeRouen, 2010). Faktor time constraints adalah permasalahan bahwa informasi yang didapat biasanya tidak komplit dan tidak akurat. Sedangkan faktor dynamic setting dalam determinan Decision Environment memungkinkan adanya perbaikan keputusan manakala keputusan awal yang diambil memberikan konsekuensi yang buruk. Kemudian, faktor familiarity menggambarkan sejauh mana pengambil keputusan mengenal kondisi yang terjadi karena memiliki kesamaan dengan kondisi sebelumnya. Dalam hal ini keputusan biasanya diambil berdasarkan intuisi dan mengabaikan SOP yang dapat mengakibatkan terjadinya overgeneralisasi. Faktor risk juga perlu dilihat karena menunjukkan 
probabilitas seorang pengambil keputusan untuk mendapat dampak negatif akibat keputusan yang diambil. Faktor stress juga penting untuk menjadi perhatian karena dapat memicu timbulnya penurunan fokus dan pengambilan keputusan yang primitif dan sangat dasar ketika krisis terjadi (Mintz \& DeRouen, 2010).

Determinan selanjutnya dalam Foreign Policy Detcision Making adalah Psychological Factors karena kondisi psikologis seorang pengambil keputusan akan berdampak pada keputusan yang diambil dalam hal apapun (Mintz \& DeRouen, 2010). Faktor yang dapat mempengaruhi determinan tersebut diantaranya cognitive consistency, images, emotions serta analogies and learning. Cognitive concistency menjadi penting karena dapat menggambarkan bagaimana pengambil keputusan dapat mengambil informasi secara tidak konsisten karena mengambil informasi yang diginkan dan sesuai dengan konsensus saja jika keputusannnya diambil oleh grup-level. Images adalah stereotype untuk mengkategorisasi isu tertentu. Images dapat berguna untuk menyederhanakan respon yang rumit namun juga berpotensi menimbulkan bias akibat simplifikasi yang berlebihan. Kemudian emotions adalah pertimbangan pemimpin untuk memutuskan berdasrakan perasaan yang umumnya didorong oleh opini publik dan media massa. Sedangkan analogies adalah konsep dimana pengambil keputusan menganalogikan satu masalah dan dampak dengan masalah serta dampak lainnya. Kemudian learning adalah proses dimana pengambil keputusan belajar untuk menganalogikan masalah secara tepat dengan mengambil pembelajaran dari kasus-kasus yang terus berkembang (Mintz \& DeRouen, 2010).

Determinan selanjutnya yang mempengaruhi Foreign Policy Decision Making adalah international factors. Determinan tersebut dipengaruhi oleh beberapa hal yakni Deterrence and arms race serta regime type of adversary (Mintz \& DeRouen, 2010). Deterrence adalah penggentaran terhadap musuh yang dilakukan sebuah negara dengan membangun pertahanan hingga sampai kepada titik bahwa negara musuh secara rasional tidak akan melakukan invasi. Sedangkan arms race berpengaruh terhadap kebijakan luar negeri karena dapat meningkatkan potensi perang. Selanjutnya, regime type of adversary juga dijadikan pijakan bagi sebuah negara untuk memprediksi langkah negara lain. Dalam konsep tersebut, negara demokrasi akan cenderung mengambil langkah damai dalam eskalasi konflik dan tidak memiliki kemampuan untuk menyatakan perang secara agresif (Mintz \& DeRouen, 2010).

Domestic factor juga menjadi salah satu determinan yang turut menentukan Foreign Policy Decision Making. Determinan tersebut dipengaruhi oleh beberapa hal yakni kepentingan ekonomi, kondisi politik dalam negeri dan opini publik (Mintz \& DeRouen, 2010). Diversionary tactic atau strategi menjadikan penggunaan kekuatan untuk tujuan popularitas politik domestik menjadi salah satu fenomena yang perlu dilihat dalam kondisi politik dalam negeri. Ancaman eksternal dapat membantu mempersatukan aktor politik domestik untuk satu tujuan tertentu. Selanjutnya faktor yang berpengaruh 
terahdap foriegn policy adalah kepentingan ekonomi. Negara akan terdorong untuk melakukan tindakan agresif untuk memenuhi resources atau kepentingan yang lebih besar yang dibutuhkan. Selain itu, opini publik juga menjadi faktor penting lainnya yang mendorong kebijakan luar negeri sebuah negara. Opini publik dapat digunakan untuk mengurangi popularitas pemerintah sehingga pengambil keputusan harus turut mempertimbangkan faktor opini tersebut (Mintz \& DeRouen, 2010).

\section{METODE PENELITIAN}

Metode yang digunakan dalam tulisan ini adalah metode kualitatif dengan pendekatan deskriptif analitis. Data yang digunakan antara lain data sekunder seperti foto, kata, kalimat (Djamba \& Neuman, 2002). Data dalam tulisan ini berupa kajian-kajian jurnal terdahulu, pernyataan pejabat kedua negara terkait serta aksi kedua negara yang tertulis pada website yang kredibel. Pendekatan ini dipilih karena aplikatif untuk megidentifikasi hal-hal yang membuat Indonesia berhasil membuat China menarik pasukannya dari ZEE Natuna dengan kekuatan militer yang jauh berada di bawah China. Selanjutnya data akan dianalisa sesuai dengan determinant variabel dari teori yang digunakan, yakni teoir Foreign Policy Decision Making.

\section{PEMBAHASAN}

Setelah Kementerian Luar Negeri Indonesia menyerahkan nota protes sehubungan dengan berdiamnya kapal-kapal China di ZEE Natuna, Pada 2 Januari 2020, Kementerian Luar Negeri China mengeluarkan pernyataan bahwa Pemerintah Indonesia harus menerima fakta bahwa China memiliki hak atas relevant waters (CNBC, 2020). Klaim China tersebut dikategorikan sebagai klaim unilateral yang berbasis pada sejarah bahwa China adalah yang pertama kali menemukan dan menamakan Pulau Nansha, membangun Nansha dan menetapkan yurisidiksi terhadap Nansha di LCS. Untuk itu, adjacent water yang wilayahnya turut melingkupi ZEE Natuna juga masuk kedalam wilayah berdaulat China (Ikeshima, 2013). Pihak Indonesia terus menolak argumen China, dan secara konsisten terus mengerahkan kapal militernya untuk menghalau keberadaan kapal nelayan, kapal penjaga pantai serta kapal perang China di wilayah ZEE-nya. Sebanyak 18 operasi siaga tempur telah disiapkan oleh TNI dalam rangka menunjukkan kesiapsiagaan Pemerintah Indoneisa dalam mengamankan wilayah ZEE Natuna (Kompas, 2020a). Kemudian pada 8 Januari 2020 China mengubah sikapnya dengan mengatakan bahwa Indonesia adalah mitra China dan sengketa teritorial hanyalah urusan sederhana (CNBC, 2020). Pada 13 Januari 2020, kapal perang Indonesia mengusir kapal nelayan China dari ZEE Indonesia tanpa mendapat perlawanan dari kapal penjaga pantai dan kapal perang China (Kompas, 2020e). 
Dengan kapasitas militer yang lebih kuat seharusnya China mempertahankan sikapnya dalam penegakan klaim di ZEE Natuna dengan tidak menghiraukan pengerahan militer dan protes Indonesia. Namun setelah militer Indonesia dikerahkan ke Natuna dan Presiden Indonesia mengeluarkan statement bahwa ZEE Natuna adalah milik Indonesia, China justru melakukan Appeasement. Dalam merespon tindakan China, Presiden Indonesia mengatakan "bahwa tidak ada yang namanya tawar-menawar mengenai kedaultan, mengenai teritorial negara kita" (Kompas, 2020b). Selain itu, Presiden Indonesia juga melakukan kunjungan kerja ke Natuna dengan didampingi oleh Kepala Staf Kepresidenan dan Panglima TNI sebagai sinyal bahwa Pemerintah Indonesia serius dalam menjaga wilayah berdaulatnya di Natuna (Kompas, 2020c). Pemerintah China akhirnya menarik kapal militernya dari ZEE Natuna dan Kementerian Luar Negeri China mengubah pernyataan "bahwa Indonesia adalah mitra strategis China, maka penyelesaian perbedaan klaim ZEE Natuna dilakukan dengan cara yang kondsuif melalui diplomasi" (Detik, 2020b).

Selanjutnya penulis mengulas tentang perilaku appeasment China terhadap Indonesia sesuai dengan determinan Foreign Policy Decision Making yakni ; (1) Decision Environment China, (2) Psychological Factors Pemimpin China; (3) International Factros; (4) Domestic Factors China (Mintz \& DeRouen, 2010).

\section{Decision Environment China}

Informasi yang didapat China tentang Indonesia mengalami overgeneralisasi karena menganggap Maritime Spat di ZEE Natuna familiar dengan Maritime Spat yang terjadi antara China dengan Filipina di wilayah perairan Filipina (Rappler, 2020b). Selama tahun 2019, setidaknya terdapat 12 kali pelanggaran wilayah oleh kapal China dimana empat kali diantaranya adalah kapal perang China dari berbagai jenis. Diketahui bahwa kapal induk Liaoning dan 4 kapal perang China lainnya memasuki wilayah perairan Filipina, namun demikian, Pemerintah Filipina hanya merespon peristiwa tersebut dengan mengirimkan nota protes saja tanpa melakukan pengerahan kapal perang. Overgenralisasi terjadi ketika China memperdiksi bahwa Indonesia akan bertindak sama dengan Filipina yakni tidak mengerahkan kapal perangnya ketika kapal perang China memasuki wilayah perairan miliknya.

Selain itu, China juga mengalami time contsraint dalam pengumpulan informasi tentang pihakpihak di internal pemerintahan Indonesia yang keras terhadap China. Sebagaimana diketahui, Menteri Perikanan dan Kelautan RI 2014 s.d. 2019, Susi Pudjiastuti melakukan inisiasi penangkapan nelayan China di ZEE Natuna yang kemudian menimbulkan Maritime Spat selama tahun 2014 s.d. 2019 (Connelly, 2017). Upaya penegakan klaim China di ZEE Natuna yang terjadi pasca dicopotnya Susi Pudjiastuti dari posisi 
Menteri Perikanan dan Kelautan RI mengindikasikan bahwa China mengira bahwa dengan tidak beradanya Susi Pudjiastuti dalam kabinet Indonesia maka respon Indonesia akan berubah. Informasi yang didapat ternyata tidak akurat karena Indonesia melalui Menteri Luar Negeri Retno Marsudi tetap melakukan perlawanan terhadap penegakan klaim oleh China di ZEE Natuna.

Keputusan awal China untuk melakukan penegakkan klaim tanpa menghiraukan protes Indonesia ternyata menimbulkan resiko karena Indonesia tidak melakukan penurunan eskalasi namun justru mengerahkan militernya ke wilayah ZEE Natuna sehingga meningkatkan ancaman konfrontasi. Mengingat dynamic setting dalam determinant Decision Environment memungkinkan adanya perbaikan keputusan manakala keputusan awal yang diambil memberikan konsekuensi yang buruk maka dalam hal ini China segera megubah kebijakannya dengan melakukan appeasment. Selain itu, China juga memiliki banyak kepentingan lain di Indonesia seperti hubungan kemitraan strategis dan Belt and Road Intitative yang terancam terdampak negatif akibat kebijakan penegakan klaim di ZEE Natuna.

\section{Psychological Factors Pemimpin China}

Menurut Mintz dan DeRouen, psychological factor dipengaruhi oleh emotions, analogies and learnings serta images. Emotions pemimpin China didorong oleh opini yang berkembang di dalam negeri China. Hal ini mendorong pengembilan keputusan pengerahan militer dalam penegakkan klaim oleh China di ZEE Natuna. Pada saat yang sama, pengambil keputusan dari pihak China juga menganalogikan penegakan klaim ZEE di Natuna secara tidak tepat sehingga menghasilkan keputusan yang hasilnya tidak diinginkan. Di sisi lain, images China terhadap Indonesia menunjukkan bahwa Indonesia adalah negara sahabat sehingga pendekatan yang lebih konstruktif masih dimungkinkan untuk dilakukan.

Media massa China menggambarkan bahwa Indonesia melakukan provokasi terhadap China. Berita secara umum menggambarkan narasi utama Pemerintah China bahwa klaim China atas ZEE Natuna telah berlangsung sejak zaman dahulu. Selanjutnya, pihak Indonesia digambarkan sebagai negara yang agresif karena menantang klaim China di Laut China Selatan, tepatnya di ZEE Natuna. Indonesia menjadi pemicu keributan di Laut China Selatan karena berkonflik juga dengan negara lain seperti Vietnam (Baijiahao.baidu, 2020). Sedangkan opini publik yang berkembang di China adalah bahwa Indonesia merupakan saingan baru China di Laut China Selatan (Blog.sina, 2020). Opini pejabat China secara langsung cukup sulit untuk ditemukan sehingga analisa dilakukan dengan melihat opini publik dan media massa yang menurut Mintz dan DeRouen dapat memicu emotions pemimpin China dalam mengeluarkan kebijakan terkait ZEE Natuna. 
Keputusan China untuk mengerahkan nelayan dan kapal perangnya ke ZEE Natuna disinyalir merupakan analogies and learning sang pengambil keputusan atas keberhasilan pengiriman kapal perang pada kasus sebelumnya ke wilayah daerah sengketa dengan Filipina. Pada 17 Februari 2019, kapal perang China jenis Korvet mengarahkan laras meriamnya ke arah kapal Korvet Filipina di Laut China Selatan atau yang dikenal dengan nama Laut Filipina Barat oleh Pemerintah Filipina. Hal ini menyebabkan kapal Filipina harus menjauh dari wilayah tersebut guna menghindari insiden (Rappler, 2020a). China juga menggunakan data keberhasilan pengusiran kapal survey Malaysia oleh kapal penjaga pantainya pada Bulan Mei 2019 (TheDiplomat, 2020). Namun demikian, pengambil keputusan di pihak China mengabaikan data bahwa Indonesia sejak tahun 2016 selalu mengerahkan kapal militernya untuk mengusir nelayan dan kapal penjaga pantai yang memasuki ZEE Natuna. Hal ini dapat dikatogrikan sebagai sebuah Cognitive consistency yang buruk dari pengambil keputusan China. Hal ini menghasilkan sebuah kebijakan yang bias dan China tidak mendapatkan hasil yang diinginkan bahwa pihak Indonesia akan menerima kehadiran militer China di wilayahnya tanpa mengkonfrontir mereka. Namun demikian, analogies dan learning ini dapat berubah dan akan menjadi pembelajaran bagi China di masa yang akan datang.

Images yang ditangkap oleh China adalah bahwa Indonesia masuk ke dalam kateogri ally, dimana Indonesia dipandang sebagai aktor yang dapat bekerja sama. Indonesia juga dipandang memiliki kapabilitas dan dimensi kultural yang setara (Kartikasari, 2019). Hal ini menyebabkan pendekatan yang lebih konstruktif masih dimungkinkan untuk dilakukan terhadap Indonesia.

\section{International Factors}

Dari segi regime type of adversary, Indonesia digambarkan sebagai sebuah negara demokrasi yang identik dengan perilaku menghindari konflik. Hal ini kemudian memicu terjadinya aksi penegakan klaim China terhadap Indonesia di ZEE Natuna dengan cara baru yakni mengerahkan kapal militer jenis frigrate. Namun demikian, hal tindakan tersebut justru mengancam strategi deterrence China di Laut China Selatan yang selama ini efektif dilakukan karena para claimant state tidak pernah bersatu untuk melawan klaim China.

Saat ini, claimant state di Laut China Selatan yang menjadi musuh China masih bergerak secara parsial dan tidak membentuk aliansi untuk bersatu melawan klaim China. Dalam hal ini, deterrence China terhadap negara-negara tersebut sangat efektif karena dari segi belanja pertahanan dan index militer, China jauh lebih kuat dibandingkan negara-negara tersebut (Chan, 2005). Namun demikian, Indonesia yang merupakan aktor penting di ASEAN berpotensi menyatukan claimant state di ASEAN untuk 
bersama-sama melawan China di Laut China Selatan. Terlebih, saat ini Amerika Serikat yang juga tengah mengadakan operasi Freedom of Navigation di Laut China Selatan akan berada pada posisi yang diuntungkan karena negara yang berkonflik dengan China bersatu dan bertambah jumlahnya. Selain itu, tidak menutup kemungkinan bahwa jika konfrontasi dengan Indonesia diteruskan, maka hal ini akan memicu tindakan balancing dari Indonesia melalui pembentukan pakta pertahanan maupun aliansi dengan Amerika Serikat. Hal ini terjadi pada Filipina yang saat ini mengancam China untuk mengundang Amerika Serikat untuk melindungi mereka dari incrusion oleh kapal-kapal China (CNBCIndonesia, 2020). Sebagaiman diketahui saat ini Indonesia melakukan strategi non balancing terhadap China yang justru menguntungkan China (Syailendra, 2017). Jika balancing oleh Indonesia benar-benar teralisasi maka hal ini akan mengubah kalibrasi deterrence China terhadap negara-negara claimant state di Laut China Selatan. Hal ini menggambarkan keinginan China yang sebenarnya yakni tidak ingin ada konflik bersenjata sekecil apapun dengan Indonesia terkait ZEE Natuna.

Regime type of adversary juga dijadikan sebagai pijakan bagi China untuk memprediksi langkah negara lain. Dalam konsep tersebut, negara demokrasi seperti Indonesia diprediksi akan cenderung mengambil langkah damai dalam eskalasi konflik dan tidak memiliki kemampuan untuk menyatakan perang secara agresif atau bahkan bertindak assertive (Mintz \& DeRouen, 2010). Dalam Maritime Spat tahun 2019, Pemerintah China mengirimkan kapal militernya ke wilayah ZEE Natuna dengan harapan bahwa Pemerintah Indonesia akan melakukan penurunan eskalasi ketegangan dan menghindari konfrontasi. Hal ini kemudian mendorong China untuk mengirimkan kapal nelayan, penjaga pantai dan militernya ke wilayah ZEE Natuna dengan prediksi bahwa Indonesia tidak akan melakukan perlawanan terhadap aksi China tersebut.

\section{Domestic Factors China}

Domestic Factors China umumnya dipengaruhi oleh beberapa hal yakni kepentingan ekonomi, kondisi politik dalam negeri dan opini publik. Secara ekonomi Indonesia cukup penting bagi China. Indonesia tidak menjadi adversary bagi China sehingga konfrontasi dengan Indonesia tidak layak dilakukan ditinjau politik domestik dan opini publik domestik. China memang melakukan Diversionary tactic atau strategi menjadikan penggunaan militer sebagai alat untuk meniakkan popularitas politik domestik. Namun strategi tersbeut dilakukan China dalam mencapai tujuan unifikasi dengan Taiwan dan menegakkan stabilitas politik di Hong Kong (CNN, 2020b). Dengan demikian jelas bahwa ZEE Natuna bukan merupakan fokus utama divesionary tactic China sehingga pendekatan yang lebih konstruktif memungkinakan untuk dilakukan. 
Di bidang ekonomi, China memiliki agenda ekonomi yang besar yakni One belt One Road (OBOR) atau Belt and Road Initiative (BRI). Indonesia merupakan negara yang cukup strategis karena letaknya yang berada di jalur utama 21 th Maritime Silk Road. Selain itu, Indonesia adalah negara nomor dua yang dikunjungi Kepala Negara China Xi Jinping, setelah Kazhakstan. China menyadari bahwa ketergantungan negara lain terhadap China dan stabilitas baik di China maupun negara mitra OBOR menjadi kunci untuk menjaga stabilitas pertumbuhan China. Untuk itu, permasalahan dengan negara mitra OBOR seperti Indonesia perlu dikesampingkan demi mencapai tujuan yang lebih besar yakni mempertahankan pertumbuhan ekonomi (Kartikasari, 2019).

Opini publik juga menjadi faktor penting lainnya yang mendorong kebijakan luar negeri sebuah negara. Namun demikian, tekanan dari publik China dalam kasus Maritime Spat dengan Indonesia di Natuna sangat rendah dan bahkan hampir tidak ditemukan. Hal ini berbeda dengan yang terjadi pada tahun 2016 ketika Susi Pudjiastuti menenggelamkan kapal nelayan China memicu kemarahan masyarakat China. Media massa China juga gencar memberitakan tentang ancaman dan tindakan tegas Menteri Susi Pudjiastuti terhadap kapal China yang akan masuk ke ZEE Natuna (Dy163, 2018). Rendahnya perhatian publik terhadap isu maritim spat di ZEE Natuna tahun 2019 s.d. 2020 menyebabkan Pemerintah China lebih fleksibel dalam melakukan appeasment setelah sebelumnya mencoba strategi assertive dalam penegakan klaim di ZEE Natuna.

Pengerahan kapal perang China serta sikap keras yang sempat ditunjukkan Pemerintah China terhadap upaya protes Indonesia disebabkan karena beberapa hal yakni pemimpin China mengalami overgeneralisasi, memperoleh informasi yang bersifat time constraint. Selain itu, keputusan tersebut juga diduga didorong oleh emotions dan opini massa di dalam negeri China tentang Indonesia. Namun demikian, tindakan assertive Indonesia dalam mempertahankan wilayah berdaulatnya membantah semua prediksi China akan sikap Pemerintah Indonesia. Jika China meneruskan sikapnya yang bersikeras mempertahankan militernya di ZEE Natuna, maka hal tersebut akan akan membahaykan strategi detterence China atas Amerika Serikat di Laut China Selatan. Selain itu, Mengingat Indonesia adalah negara dipandang memiliki image Ally dan regime type of adverseries sebagai negara demokrasi yang cenderung menghindari konflik, maka China memutuskan untuk melakukan dynamic setting dengan mengubah kebijakan yang sebelumnya bersikeras keras menjadi Appeasement. Dengan demikian, hal ini menjawab pertanyaan mengapa China yang kekuatan militernya di atas Indonesia justru melakukan Appeasement terhadap Indonesia dalam kasus sengketa batas geografis di ZEE Natuna. 


\section{SIMPULAN}

Dari segi Decision Environment, Overgeneralisasi menjadi salah satu faktor yang mendorong China mengabaikan nota protes Indonesia. Pihak China mengaggap bahwa kasus penegakan klaim Nine Dash Line di ZEE Natuna akan memiliki hasil yang sama dengan penegakan klaim Nine Dash Line terhadap wilayah teritorial Filipina di Laut Filipina Barat. Selain itu, China juga mendapatkan informasi yang bersifat time contsraint terutama dalam memprediksi langkah Indonesia dalam menghadapi penegakan klaim oleh China di wilayah ZEE-nya. Pihak China mengira bahwa pergantian Menteri Kelautan dan Perikanan Indonesia pada tahun 2019 akan melemahkan sikap Indonesia dalam mempertahankan ZEE Natuna dari perilaku agresif China. Namun demikian, pergantian kabinet tidak merubah sikap Indonesia.

Dari segi Psychological Factors, opini masyarakat yang mendesak Pemerintah China untuk bertindak tegas mempengaruhi emotions pemimpin China sehingga diambillah opsi pengerahan militer dalam rangka penegakkan klaim Nine Dash Line di ZEE Natuna. Pada saat yang sama, pengambil keputusan dari pihak China juga menganalogikan penegakan klaim ZEE di Natuna dengan kasus serupa secara tidak cermat sehingga menghasilkan keputusan yang salah. Namun di sisi lain, images China terhadap Indonesia menunjukkan bahwa Indonesia adalah negara sahabat sehingga perubahan kebijakan yang lebih konstruktif masih mungkin berhasil untuk dilakukan.

Dari segi international factors, Indonesia yang secara regime type of adverseries identik sebagai negara damai yang cenderung menghindari konflik memungkinkan China untuk mencoba opsi pengerahan militer dalam penegakan klaimnya di wilayah ZEE Indonesia. Namun demikian, reaksi Indonesia. Sedangkan dari segi Domestic Factors, Posisi Indonesia cukup penting bagi kepentingan ekonomi domestik China. Selain itu, China juga tidak menerapkan Diversionary tactic dalam ZEE Natuna sebagai strategi untuk menaikkan popularitas politik domestik. Penerapan strategi tersebut lebih ditekankan pada isu yang lebih krusial seperti unifikasi dengan Taiwan serta penegakan stabilitas politik dan keamanan di Hong Kong.

Penegakan klaim Nine Dash Line oleh China di ZEE Natuna dilakukan dengan informasi dan kalkulasi yang salah. Kesalahan cukup fatal pihak China adalah menganggap bahwa Indonesia akan melunak terhadap tindakan agresif China pasca Indonesia mengalami pergantian kabinet. Mereka tidak mengantisipasi respon Indonesia yang konsisten menolak kehadiran kapal China di ZEE Natuna. China akhirnya sadar bahwa aksi mereka terhadap Indonesia di ZEE Natuna dapat memunculkan konsekuensi serius terhadap posisi China mereka di LCS. Untuk itu, pihak China mengubah sikap mereka terhadap Indonesia dengan meralat statement mereka terkait nota protes dan menarik mundur seluruh kapal mereka dari ZEE Natuna. Di sisi lain, langkah yang diambil Pemerintah Indonesia sudah sangat tepat 
karena melakukan tindakan yang tegas namun terukur seperti mengimbangi kehadiran kapal militer China dengan menghadirkan kapal militer serupa di ZEE Natuna.

\section{DAFTAR PUSTAKA}

Aster, S. (2008). Appeasement. Before and after revisionism. International Journal of Phytoremediation, 19(3), 443-480. https://doi.org/10.1080/09592290802344962

Baijiahao.baidu. (2020). 中国警告都不听? 印尼两次挑战中国南海主权, 我外交部重磅发声. https://baijiahao.baidu.com/s?id=1654848048659044679\&wfr=spider\&for=pc

Blog.sina. (2020). 印尼：南海上的中国新对手？－凤凰周刊_新浪博客. http://blog.sina.com.cn/s/blog_4b8bd1450102vd7o.html

Castro, R. C. De. (2020). Abstract of from Appeasement to soft balancing: the duterte administration's shifting policy on the South China Sea imbroglio. Asian Affairs(UK), $\quad 0(0), \quad 1-27$. https://doi.org/10.1080/00927678.2020.1818910

Chan, S. (2005). IS THERE A POWER TRANSITION BETWEEN THE U.S. AND CHINA ? The Different Faces of National Power. 45(5), 687-701.

Chang, D. W. (2003). The Western Power s and Japan's Aggression in China: The League of Nations and The Lytton Report. 10(1), 43-63.

CNBC. (2020). Sikap China Berubah 180 Derajat, Kini Tak Galak Soal Natuna. https://www.cnbcindonesia.com/news/20200110074535-4-129030/sikap-china-berubah-180derajat-kini-tak-galak-soal-natuna

CNBCIndonesia. (2020). Filipina: China Menyerang, Kami Telepon AS. https://www.cnbcindonesia.com/news/20200827120230-4-182389/filipina-china-menyerang-kamitelepon-as

CNN. (2020a). Kronologi Kapal Nelayan China Terobos Perairan Dekat Natuna. 2020. https://www.cnnindonesia.com/internasional/20200103124754-106-462119/kronologi-kapalnelayan-china-terobos-perairan-dekat-natuna

CNN. (2020b). Live updates: Hong Kong protesters hit the streets as China marks National Day. https://edition.cnn.com/asia/live-news/china-hong-kong-oct-1-live-intlhnk/h_839e8f86f979ae798e6790793cea71d8

Connelly, A. L. (2017). Indonesia di Laut Cina Selatan: Berjalan sendiri. Lowly Institute, April.

Cruz de Castro, R. (2017). The Duterte Administration's Appeasement policy on China and the crisis in the Philippine-US alliance. Philippine Political Science Journal, 38(3), 159-181. https://doi.org/10.1080/01154451.2017.1412161

De Castro, R. C. (2019a). China's Belt and Road Initiative (BRI) and the Duterte Administration's Appeasement Policy: Examining the Connection Between the Two National Strategies. East Asia, 36(3), 205-227. https://doi.org/10.1007/s12140-019-09315-9

De Castro, R. C. (2019b). Explaining the duterte administration's Appeasement policy on China: The power of fear. Asian Affairs, 45(3-4), 1-27. https://doi.org/10.1080/00927678.2019.1589664

De Castro, R. C. (2019c). The Philippines and the maritime security order in Southeast Asia: The risks of an Appeasement policy on an expansionist China. Contemporary Chinese Political Economy and Strategic Relations, 5(3), 1035-1078.

Detik. (2020a). Kapal-kapal Militer RI Dikerahkan Jaga Natuna dari Klaim China. https://news.detik.com/berita/d-4846099/kapal-kapal-militer-ri-dikerahkan-jaga-natuna-dari-klaimchina

Detik. (2020b). Kapal Perang China Masih Mondar-mandir di Natuna. https://news.detik.com/berita/d4850639/kapal-perang-china-masih-mondar-mandir-di-natuna

Djamba, Y. K., \& Neuman, W. L. (2002). Social Research Methods: Qualitative and Quantitative Approaches. In Teaching Sociology (Vol. 30, Issue 3). https://doi.org/10.2307/3211488 
Dy163. (2018). 炸沉中国船的印尼女部长强硬表态: 中国在犯罪历史的经典_网易订阅. https://www.163.com/dy/article/DUIE02KT0522W79J.html 炸沉中国船的印尼女部长强硬表态：中国 在犯罪 历史的经典 dan http:/mil.news.sina.com.cn/2014-12-09/1813814644.html

Fravel, M. T., \& Fravel, M. T. (2018). Power Shifts and Escalation: Explaining China's Use of Force in Territorial Disputes Linked references are available on JSTOR for this article: Power Shifts and Escalation. 32(3), 44-83.

Ikeshima, T. (2013). China's Dashed Line in the South China Sea: Legal Limits and Future Prospects. Waseda Global Forum, 10, 17-50.

Kartikasari, A. (2019). Indonesia's Image from China's Perspective on South China Sea Dispute (A Preliminary Study on China's Perception on Indonesia). Global: Jurnal Politik Internasional, 21(2), 176. https://doi.org/10.7454/global.v21i2.404

Kennedy, P. M. (1976). The tradition of Appeasement in British foreign policy 1865-1939. British Journal of International Studies, 2(3), 195-215. https://doi.org/10.1017/S0260210500116699

Kompas. (2020a). Amankan Laut Natuna, TNI Siapkan 18 Operasi Siaga Tempur Halaman all Kompas.com. 2020. https://regional.kompas.com/read/2020/01/05/14070091/amankan-laut-natunatni-siapkan-18-operasi-siaga-tempur-?page=all

Kompas. (2020b). Jokowi soal Natuna: Tak Ada Tawar-menawar mengenai Kedaulatan Kita Halaman all Kompas.com. https://nasional.kompas.com/read/2020/01/06/14213021/jokowi-soal-natuna-takada-tawar-menawar-mengenai-kedaulatan-kita?page=all

Kompas. (2020c). Kunjungi Natuna, Jokowi Ingin Tunjukkan Kedaulatan RI Halaman all - Kompas.com. https://nasional.kompas.com/read/2020/01/08/13075561/kunjungi-natuna-jokowi-ingin-tunjukkankedaulatan-ri?page $=$ all

Kompas. (2020d). Soal Natuna, Menlu Retno Minta China Patuhi Wilayah ZEE Sesuai UNCLOS 1982 Halaman all - Kompas.com. https://nasional.kompas.com/read/2020/01/03/16070571/soal-natunamenlu-retno-minta-china-patuhi-wilayah-zee-sesuai-unclos-1982?page=all

Kompas. (2020e). TNI Tegaskan bila Kapal China Kembali Lagi ke Natuna Akan Ditangkap dan Diproses secara Hukum. https://regional.kompas.com/read/2020/01/13/14101691/tni-tegaskan-bila-kapalchina-kembali-lagi-ke-natuna-akan-ditangkap-dan

Küntzel, M. (2014). Obama's New Iran Policy: Is America Drifting toward Appeasement? Israel Journal of Foreign Affairs, 8(2), 25-36. https://doi.org/10.1080/23739770.2014.11446586

Mintz, A., \& DeRouen, K. (2010). Understanding foreign policy: Decision making. Understanding Foreign Policy: Decision Making, January, 1-168. https://doi.org/10.1017/СBO9780511757761

Niquet, V. (2019). China Maritime Strategy Since 2018: Tactical Appeasement or Strategic Evolution? 3(2), $1-8$.

Rappler. (2020a). Chinese warship targeted Philippine Navy vessel in West PH Sea - AFP. https://www.rappler.com/nation/afp-says-chinese-warship-targeted-navy-vessel-west-philippinesea-april-2020

Rappler. (2020b). LIST: China's incursions in Philippine waters. https://www.rappler.com/newsbreak/iq/listchina-incursions-philippine-waters

Renshon, J., \& Renshon, S. A. (2008). The theory and practice of Foreign Policy Decision Making. Political Psychology, 29(4), 509-536. https://doi.org/10.1111/j.1467-9221.2008.00647.x

Syailendra, E. A. (2017). A nonbalancing act: Explaining Indonesia's failure to balance against the Chinese threat. Asian Security, 13(3), 237-255. https://doi.org/10.1080/14799855.2017.1365489

TheDiplomat. (2020). Vietnam Confronts China, Alone - The Diplomat. https://thediplomat.com/2019/09/vietnam-confronts-china-alone/

Trubowitz, P., \& Harris, P. (2015). When states appease: British Appeasement in the 1930s. Review of International Studies, 41(2), 289-311. https://doi.org/10.1017/S0260210514000278

Viotti, P. R., \& Kauppi, M. V. (2012). International Relations and Politics. In The ANNALS of the American Academy of Political and Social Science (Vol. 504, Issue 1). https://doi.org/10.1177/0002716289504001014 